\title{
Increase adherence to waste management policy at healthcare facility in Egypt
}

\author{
Amal Aboelnour ${ }^{1 *}$ and Manal H. Abuelela ${ }^{2}$
}

\begin{abstract}
Background: Proper management of medical wastes can help prevent serious consequences of catastrophic events or accidents in the hospital and its near or far environment.

Method: A quality performance improvement project has been carried out to increase adherence to waste management policy of infection control, to ensure that departments are following basic health rules of their communities. In this project, the team utilized the basic Six Sigma breakthrough problem-solving methodology: Define, Measure, Analyze, Improve and Control (DMAIC) to examine the original (root) causes of the problem, in a healthcare facility in Egypt from January to August 2016. The team re-modulated a place for interim storage of hospital-regulated hazardous medical waste and compensate for workers' fatigue by participation of professional housekeeping company.

Results: Weekly recording of errors in performance in waste management process demonstrates process stability through the first 12 weeks, and shifting towards the desired direction of reduced errors in waste management performance was obtained from the 13th week ongoing.

Conclusion: Infection preventionists using their routine monitoring data could help the organization to fulfill accreditation requirements for quality assurance through the performance improvement project and to keep all hospital staff, visitors, and the surrounding environment safe and secure.
\end{abstract}

Keywords: Regulated hazardous waste, Interim storage, Quality improvement, Infection preventionists, Six sigma

\section{Introduction}

Wastes generated by healthcare facilities are divided into $85 \%$ non-hazardous waste which is generated by administrative departments and general cleaning work within the hospital and is treated similarly to general/municipal waste. Hazardous medical waste is generated from contaminated sources or potentially contaminated with infectious, chemical, or radioactive sources that pose a potential risk to health. This constitutes a small percentage of $15 \%$ of total healthcare waste (WHO Fact Sheet 2018; Martin 2005). The major categories of hazardous waste include the following: Infectious waste: waste contaminated with blood and blood products, other body secretions, or items contaminated with them (e.g., diagnostic samples); cultures and stocks of infectious

\footnotetext{
* Correspondence: amalaboelnour@gmail.com

${ }^{1}$ Infection Control Unit, Microbiology and Immunology Unit, Department of Microbiology and Parasitology, Research Institute of Ophthalmology (RIO), Giza 12611, Egypt

Full list of author information is available at the end of the article
}

microorganisms from laboratory work; or waste from patients with infections (e.g., discarded bandages and wound covering and disposable medical devices like urinary or venous catheters); pathological waste: fragments of human tissues, organs, non-viable fetuses, placenta, organs or fluids, body parts, and contaminated animal carcasses; sharps waste: used needles, syringes, disposable blades, and scalpels, etc.; chemical waste: solvents and reagents from laboratory, disinfectants, sterilants used in reprocessing of medical devices, and heavy metals contained in medical devices (e.g., mercury in broken thermometers) and batteries, exhibiting at least one of the following properties: toxic, flammable, corrosive, reactive or genotoxic; pharmaceutical waste: unused, expired, or contaminated vaccines, sera and drugs; cytotoxic waste: waste containing substances with genotoxic properties (i.e., carcinogenic, mutagenic, or teratogenic chemicals), such as cytotoxic drugs used in cancer treatment and their metabolites; and Radioactive waste: 
All materials contaminated with nucleotides of radioactive substances that are used in nuclear medicine, radiotherapy, or in cancer diagnosis and treatment (Ale Livs 2013).

There are about 16 billion injections calculated to be administered every year throughout the world. Needles and syringes are not all discarded safely, with a possibility of reuse, making high risk of infection and injury. Thirty-three thousand eight hundred new cases of HIV, 315,000 cases of HCV infections, and 1.7 million cases of HBV infections were encountered in 2010 as adverse effects of unsafe injections (Pépin et al. 2014). A person who experiences one needle-stick injury from a needle used on an infected source patient has risks of $30 \%, 1.8 \%$, and $0.3 \%$ respectively of becoming infected with $\mathrm{HBV}, \mathrm{HCV}$, and HIV. Additional hazards occur from searching in waste disposal sites and during the handling and manual segregation of hazardous waste from health-care facilities. The waste handlers are at immediate risk of needle-stick injuries and exposure to toxic or infectious materials (Ale Livs 2013). A disposal plan should be made for the collection, handling, predisposal treatment, and terminal disposal of medical wastes. Trained persons should be designated to be responsible for establishing, monitoring, reviewing, and applying the plan. Sharp waste should be placed into puncture-proof containers located as close as possible to the point of use. Used syringe needles should not be bent, recapped, or broken before discarding them into a container. Regulated medical wastes temporary stored awaiting treatment should be placed in a well-ventilated area that is inaccessible to neither insects nor animals. If the final treatment of the medical waste cannot be done at the site of its generation, regulated medical waste should be transported in closed, rigid containers to the final treatment site. Treatment methods of regulated medical wastes include (steam sterilization, incineration, burial, or microwave treatment). Microbiological wastes must be first inactivated in the laboratory (e.g., by autoclaving) before transport to a sanitary landfill. Safe disposal of liquid infectious waste, blood, suctioned fluids, ground tissues, excretions, and secretions, can be done through sanitary sewers, on the condition that local sewage discharge requirements are fulfilled and that the authority has accepted this to be an appropriate method of disposal (Recommendations of CDC and the Healthcare Infection Control Practices Advisory Committee (HICPAC) 2003). The infection preventionists (IPs) play a key role in improving quality of health care, since they consistently collect definition-driven wealth of data, they routinely use data to monitor practices and outcomes, and they can help their organization to fulfill accreditation requirements for quality assurance and performance improvement (QAPI) programs (Fakih et al. 2013; Freidman et al. 2008). The Six Sigma DMAIC (an acronym for Define, Measure, Analyze,
Improve, and Control) methodology is a data-driven improvement cycle used for improving, optimizing, and stabilizing processes and designs (Quinn 2018). Quality improvement essential tools includes the tools and templates needed to launch a successful quality improvement project and manage performance improvement, e.g., cause and effect diagram, flow chart, Pareto diagram, control chart, etc. (Langley et al. 2009). A waste management improving program was designed according to evidence-based best practices.

The aim of the work is to improve the performance of the existing waste management system in the facility, through conducting a quality improvement project to initiate some action plans to organize and control the waste management process according to infection control policy and to build awareness/consciousness among hospital staff.

\section{Methods}

This project focused on improving waste management in the facility utilizing the basic Six Sigma breakthrough problem-solving methodology DMAIC. It consists of five phases: Define, Measure, Analyze, Improve, and Control (Langley et al. 2009; Arthur 2016).

\section{Hospital in brief}

The healthcare facility is a referral ophthalmic research center, with daily attendance of more than 400 patients referred from all governorates of Egypt at general outpatient and specialized clinics, of which an average of 40 patients are submitted to operative procedure. The average amount of waste output is $100 \mathrm{~kg} /$ day of normal waste in addition to $30 \mathrm{~kg} /$ day infectious or medical waste.

\section{Define step Identify a project}

After analyzing the process of waste management at hospital, it was noticed that complaints about its performance have been increased, and the hospital was penalized for improper waste disposal. The hospital administration decided to focus on waste management as an improvement opportunity. Hospital administration adopted the head of infection control unit, public health, and quality resource office to increase adherence to waste management policy, and they nominate this project.

\section{Select a project}

Through the risk assessment, the infection control team and quality resource officer have selected this project according to probability, impact, and preparedness among some other suggested projects (Table 1) such as redevelop waste incinerator service within the hospital or improve the water boilers system in the hospital. 


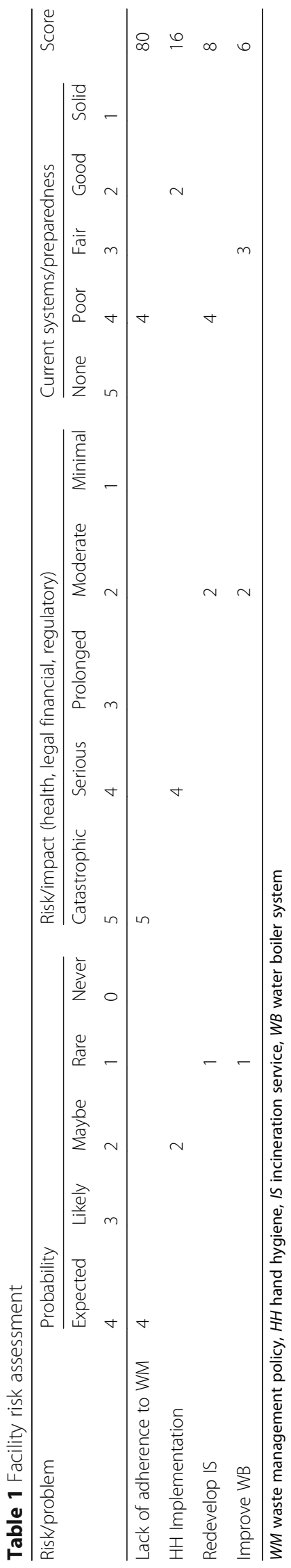


In addition, increase adherence to waste management policy was the project of choice because it met the following points: it corrected a continues problem; it was expected to finish within 6 to 7 months; it had great impact on patients, healthcare workers (HCWs), and employees satisfaction; significant results were expected; it reduced the cost of poor quality; it had low potential resistance; and it improved a critical health problem.

Lack of adherence to proper waste management plan would increase the health care-associated infection (HAIs) especially to risk groups: HCWs, patients, visitors, other employees, and workers at waste disposal facilities.

\section{Establish the project}

Mission statement: Increase adherence rate to waste management policy in hospital to the maximum within 6 months.

Select project team: The team included infection preventionist (IP), medical director, head of the housekeeping department, quality resource officer, and staff from the following areas: nursing, public health, engineering department, and house-keeping. The team had regular meetings once per week and offered enough time to manage the mission.

The team specified the most possible causes matching with the available data and ranked them according to severity.

The multidisciplinary team had complete authority support.

Benefits: The objective is tied to the hospital's strategic goals of high patient and employee satisfaction rates and good service and care at the lowest possible cost.

Verify the mission: The team assured data access and data measurement. Team members represent the appropriate parts of the organization participating in the process.

\section{Measure step}

Project scope: The process of waste management starts from all departments and end by hand over medical waste to nearby veterinary hospital for incineration and non-infectious waste to General Organization of Cleaning and Beauty.

Goal statement: Increase adherence to waste management policy $80-90 \%$.

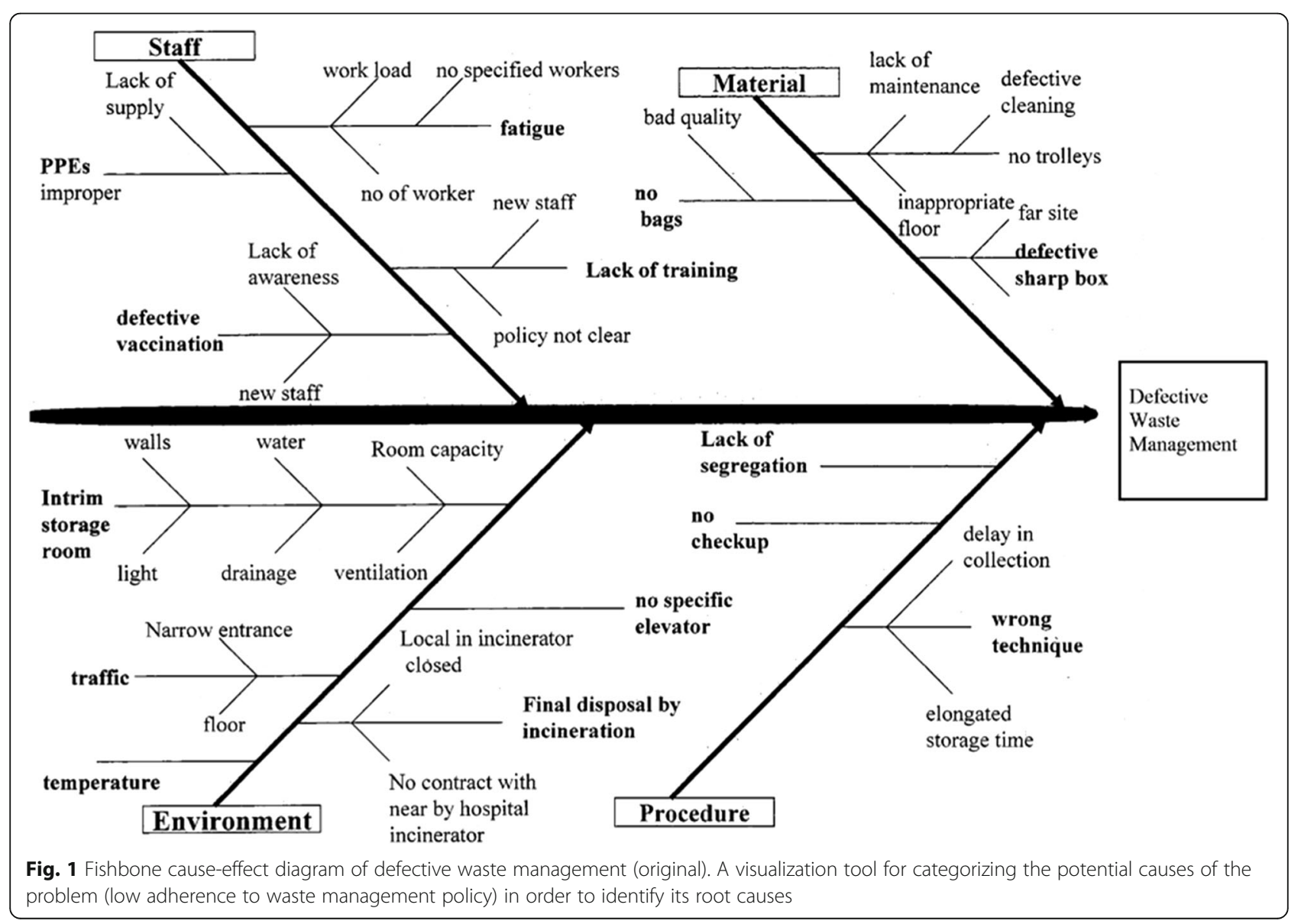


Project schedule: Define: 2/2016, Measure: 3/2016, Analyze: 4/2016, Improve: 5, 6/2016, Control: 7/ 2016.

Operational definition: An error of performance in waste disposal was considered to exist if there is (1) inappropriate segregation, (2) inappropriate handling (transport), (3) lack of supplies (trash trolleys, bins, sharps containers, and black and red plastic waste bags), (4) defective personal protective equipment (PPE), (5) inappropriate sharp disposal, and (6) inappropriate interim waste storage.

\section{Analyze step}

Brainstorming was performed by team members for a 15-min session trying to identify the probable causes of the problem. Theories were clarified and arranged in groups according to similarities. Cause and effect diagram in a fishbone design (Fig. 1) was a visualization tool for categorizing the potential causes of the problem in order to identify its root causes, as well as helping the team members to generate additional ideas.

Test theories: The team specified the most possible causes matching with the available data and ranked them according to severity.

Audit tool (checklist): A checklist was developed (Table 2) to gather information about wrong performance in waste disposal process according to the National Infection Control Manual and CDC guidelines for medical waste (Qandil et al. 2016; CDC-DHHS (NIOSH) 2004).

A pilot test for the checklist was performed in OR waste disposal steps, and the checklist was reviewed and evaluated. Then, the IP worked daily to collect data from all departments starting with waste segregation till interim storage of waste over a period of 6 weeks. The results were collected and analyzed by team members, and five main variables were encountered. These included defective interim storage using the old incinerator room for this purpose, insufficient number of workers mostly with bad general health condition who carry out steps of waste disposal, no rigid containers to transport the waste bags to storage place, segregation of waste at origin of production was sometimes wrong in addition to faulty sharp disposal, and deficient training of workers in waste management process as shown in (Table 3).

Pareto diagram was developed (Fig. 2) by finding the cumulative percentage of the total effect of the ranked causes (the five main variables) to identify the vital few root causes which contribute to $80 \%$ of the problem so that priorities for improvement can be established (Alzahrani and Jazieh 2018). In our work, both the defective interim storage, using the old incinerator place and big containers in the backyard of the facility to store all the waste till the time of hand over, and fatigue of work, due to shortage of number of workers, constituted the main root causes of the problem.
Table $\mathbf{2}$ Check list of performance of waste disposal

\begin{tabular}{|c|c|c|c|}
\hline & Subject & Yes & No \\
\hline 1 & $\begin{array}{l}\text { Presence of red and black waste bags in all } \\
\text { patient care areas }\end{array}$ & & \\
\hline 2 & $\begin{array}{l}\text { Red bags present near places of infectious } \\
\text { waste production }\end{array}$ & & \\
\hline 3 & $\begin{array}{l}\text { Waste bags are tied and changed per shift } \\
\text { or when } 3 / 4 \text { th full }\end{array}$ & & \\
\hline 4 & There is waste segregation at the origin & & \\
\hline 5 & $\begin{array}{l}\text { Presence of scattered waste outside waste } \\
\text { bags }\end{array}$ & & \\
\hline 6 & $\begin{array}{l}\text { Regulated medical waste is transported in } \\
\text { rigid, leak-proof containers, strong enough } \\
\text { to avoid tearing or bursting during handling, } \\
\text { and sealed during transport }\end{array}$ & & \\
\hline 7 & $\begin{array}{l}\text { There is data sticker (biohazard symbol, } \\
\text { generator name, and type of waste) } \\
\text { attached to each package of regulated } \\
\text { medical waste. }\end{array}$ & & \\
\hline 8 & $\begin{array}{l}\text { Containers, used to hold regulated medical } \\
\text { waste, decontaminated when necessary }\end{array}$ & & \\
\hline 9 & $\begin{array}{l}\text { Workers are wearing personal protective } \\
\text { equipment PPE }\end{array}$ & & \\
\hline 10 & $\begin{array}{l}\text { Workers use safe method of waste } \\
\text { manipulation and transportation to interim } \\
\text { store }\end{array}$ & & \\
\hline 11 & $\begin{array}{l}\text { Interim storage room is cleaned daily, } \\
\text { protected from animals, pests, and rodents }\end{array}$ & & \\
\hline 12 & $\begin{array}{l}\text { The door of interim storage room is kept } \\
\text { closed to prevent unauthorized access }\end{array}$ & & \\
\hline 13 & $\begin{array}{l}\text { Sharp containers are put as near as possible } \\
\text { to the origin of sharp waste }\end{array}$ & & \\
\hline 14 & $\begin{array}{l}\text { Sharp containers are closed and disposed } \\
\text { when } 3 / 4 \text { th full }\end{array}$ & & \\
\hline 15 & $\begin{array}{l}\text { There are waste bags stored outside storage } \\
\text { room }\end{array}$ & & \\
\hline 16 & $\begin{array}{l}\text { There is log documenting waste delivery } \\
\text { out of hospital }\end{array}$ & & \\
\hline 17 & $\begin{array}{l}\text { There is schedule of daily transfer of } \\
\text { hazardous waste by car to incineration }\end{array}$ & & \\
\hline
\end{tabular}

Table 3 Total effect of the ranked causes according to their frequency

\begin{tabular}{llll}
\hline Category & Frequency & Percent of total & Cumulative \% \\
\hline Interim storage & 100 & 50 & 50 \\
Fatigue & 50 & 25 & 75 \\
Lack of supply & 20 & 10 & 85 \\
Segregation & 15 & 7.5 & 92.5 \\
Sharp disposal & 12 & 6 & 98.5 \\
Timeliness/training & 3 & 1.5 & 100 \\
Grand total & 200 & 100 & 100 \\
\hline
\end{tabular}




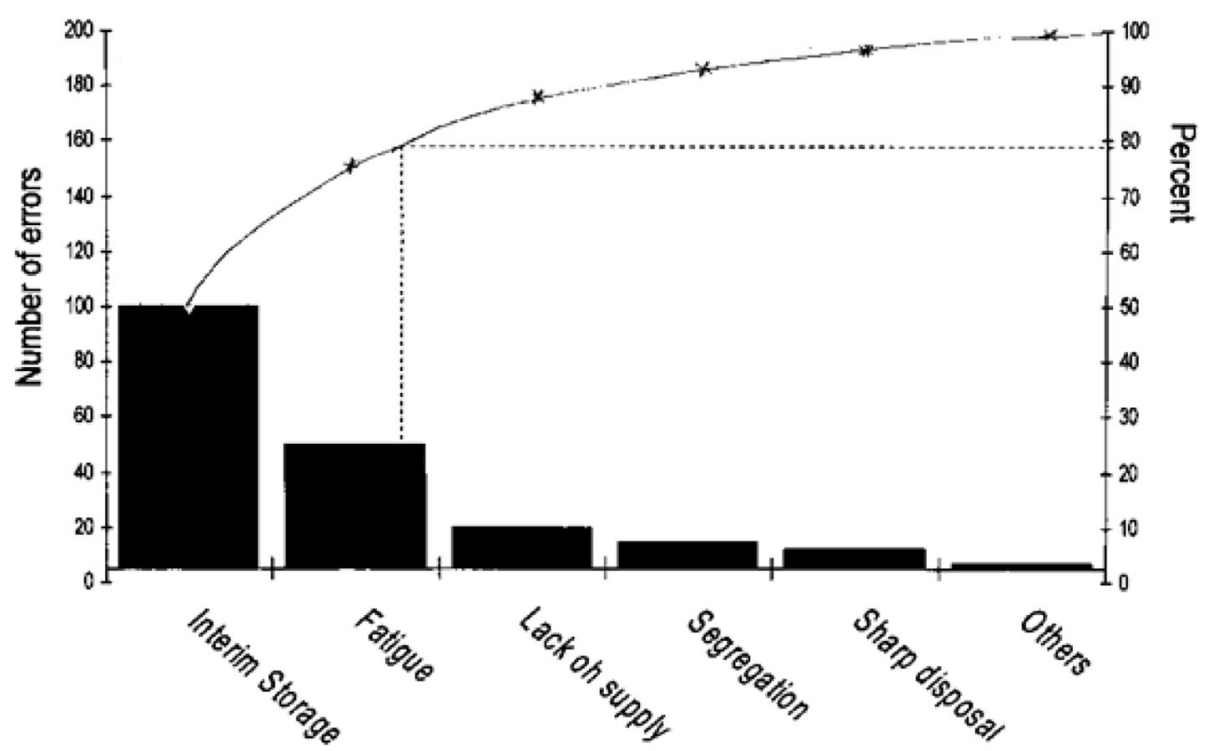

Fig. 2 Pareto diagram of figure and percentage of risk score in waste management process. It shows the (cumulative-percent) of the total effect of the ranked causes of the problem to identify the vital few root causes which contribute to $80 \%$ of the problem

\section{Improve step}

After receiving the data collected and analyzing the results, the team listed several creative new improvement solutions (Table 4). Remedy 1: Renew the old interim storage room (incinerator room). Remedy 2: Build a new room for interim storage in the backyard from glass and aluminum. Remedy 3: Use the office room beside the kitchen (already existing room) for interim storage of waste. The selected remedies had been assessed against certain criteria including total cost, impact on problem, benefit/cost, resistance to change, implementation time, uncertain effectiveness, and health safety.

Design the remedy: All the team members agreed to use the previous office room beside the kitchen as the interim storage room of waste; it lies in the ground floor, its size is big enough to accommodate hospital waste up

Table 4 Improvement solutions criteria

\begin{tabular}{llll}
\hline Criterion & Remedy $1^{*}$ & Remedy $2^{* *}$ & Remed y3 $3^{* * *}$ \\
\hline Total cost & 2 & 1 & 6 \\
Impact on problem & 1 & 3 & 5 \\
Benefit/cost & 3 & 2 & 5 \\
Resist to change & 1 & 3 & 4 \\
Implementation time & 2 & 1 & 7 \\
Uncertain effectiveness & 1 & 2 & 6 \\
Health safety & 2 & 1 & 5 \\
Score & 12 & 13 & 38 \\
\hline
\end{tabular}

*Remedy 1: Renew the old interim storage room (incinerator room)

**Remedy 2: Build a new room for interim storage in the backyard from glass and aluminum

***Remedy 3: Use the office room beside the kitchen (already existing room) for interim storage of waste to $48 \mathrm{~h}$ and more, both walls and floors are covered with tiles which can be easily cleaned with soap and water, there is water supply connection and light source, it lies near to the elevator and can be assessed through a corridor after the elevator, and it was no more needed for use by kitchen staff. However, limitations had been encountered in this remedy as follows: inadequate ventilation of the chosen room; this was solved by applying big wall exhaust fan. The chosen room had a door that opened towards the inside of the kitchen. This door was permanently closed, and another door was made that opened towards the backyard of the facility and the back gate through which waste delivery out of hospital to final disposal took place. Hand hygiene station (a sink with water supply and drainage connection) was to be added. In addition, to solve the problem of process fatigue in waste management and environmental cleaning as well, the team requested contracting with proficient housekeeping company through the administration as the workers of the facility were not enough to carry the entire workload, becoming more and more elder, and having increased absence due to chronic diseases. The team designed a plan to show the procedures of operating remedy (Fig. 3), starting from choosing a desired place to use as interim storage room as previously mentioned. Engineering department was consulted to do the structural changes needed. Administration agreement was obtained before starting the work and also for contracting with the housekeeping company. We started staff training including nurses in all departments and waste transporters. We put a schedule for waste collection, transport to interim storage room, and final 


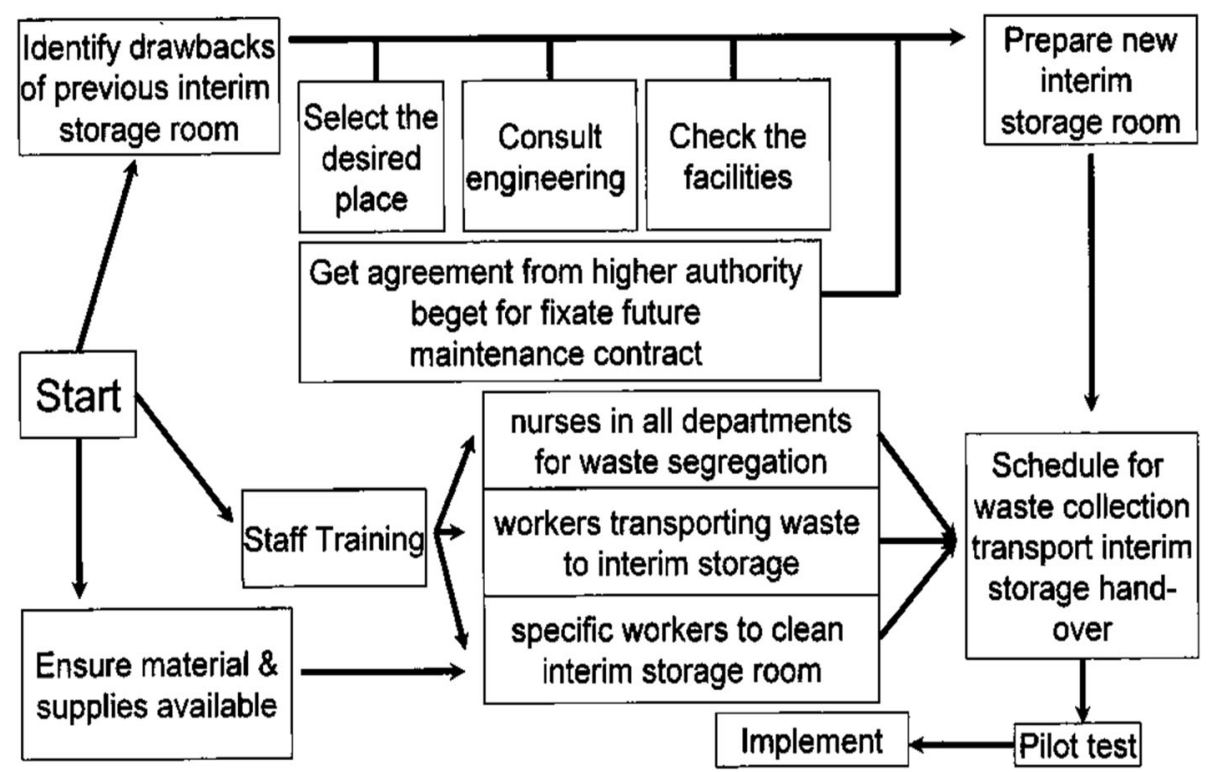

Fig. 3 The plan of the procedures of operating remedy

hand-over out of the facility. Materials and supplies including red bags, trollies, and personal protective equipment had been checked to be available any time.

Prove effectiveness and implement: Waste disposal from the operative theater was the limit scale to perform the pilot test of the new interim waste storage room. The outcome was very successful. The improving project showed remarkable increase in adherence to waste management policy in operative theater. Before implementation, all nursing staff, workers of the new housekeeping company, the old workers, and even physicians were submitted to training and education on the proper steps of safe waste management, how to avoid stick injury and blood and body fluid exposure, and how to manage if the exposure happened, with a referral comparison between previous performance which was unsafe for the health of patients, all employees, and even visitors, in addition to the surrounding environment, and the new improved safe waste management steps.

\section{Results}

\section{Control step}

Process outcome: The team designed a control chart (Fig. 4) to weekly monitor errors in performance in waste management process (as shown before in operational definition) using checklist to assess the stability of the improvement, i.e., when the stream of data falls within control limits based on plus or minus three standard deviation (3 sigma) of the central line (the mean). The chart showed process stability through the first 12 weeks, and shifting towards the desired direction of reduced errors in waste management performance was obtained from the 13th week ongoing (more than eight data records on the same side of line of the mean value).

Control measures: to sustain the improvement, the team instituted the following measures:

- Orientation programs for physicians, nurses, and workers, including in-service training.

- Continuing audit tool of chick list for waste disposal performance.

- Visual education by posters and signs on proper waste management steps.

- Ongoing training and orientation for new residents, nurses, and housekeeping workers.

- The team had determined the actual standard for the process steps to go through quality control follow-up (Table 5). We established control standards to be less than $0.3 \%$ error in solid waste bags disposal and in cleaning of interim storage room, $0.5 \%$ in timeliness, and $0 \%$ in sorting, sharps disposal, or returning to historic mistake.

- New high-level flow diagram had been designed to show the more detailed steps of proper waste management performance (Fig. 5). Disposal of liquid chemical waste would follow pharmacy guidelines: non-chemical fluid waste to be disposed off through the normal drainage system, sharps waste through safety box then to be collected in red bags, and solid infectious non-sharp waste to be collected in red bags and finally hand over to the nearby hospital of Veterinary Medicine for incineration, and solid radiation waste to be collected in yellow bags with sign on top then transported to the atomic energy 


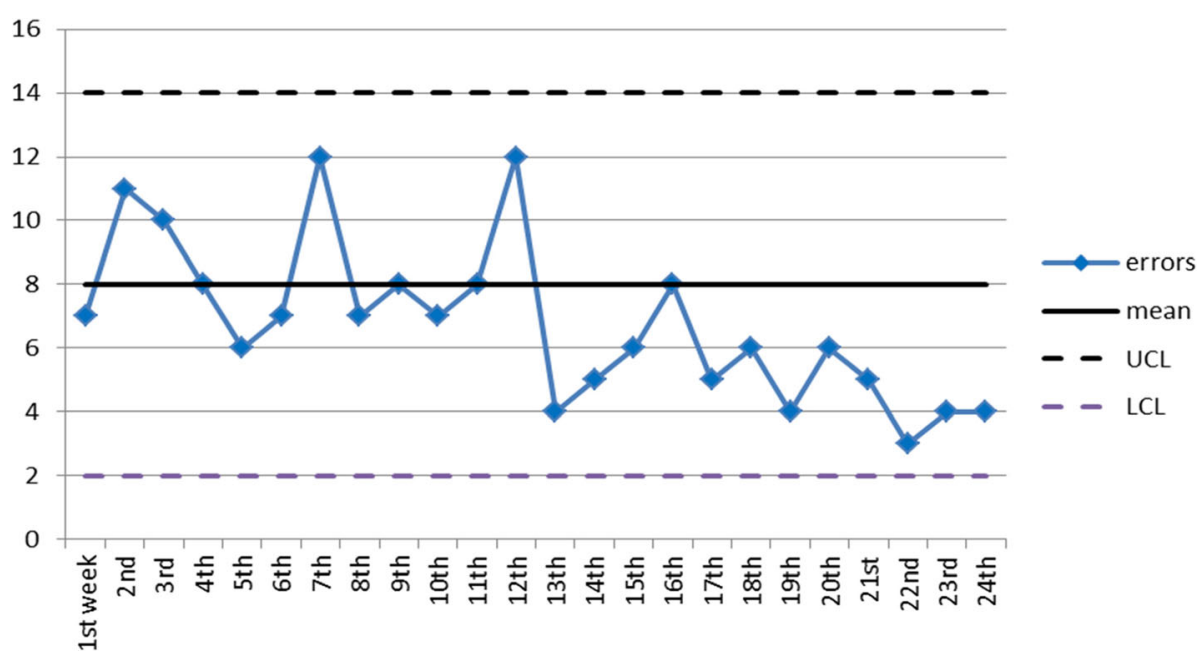

Fig. 4 Control chart of waste management performance errors. Weekly monitoring of errors in performance in waste management process as a process outcome measure, showing data shift by decreasing performance errors in waste management performance from the 13th week ongoing

institute, solid ordinary noninfectious waste to be collected in black bags and finally hand over to the General Authority of Cleaning and Beauty.

\section{Discussion}

Quality and quality improvement in healthcare have always been an assumed component of infection prevention. "Performance improvement" (PI) is an ongoing process for improving individual performance and the systems of care within the healthcare facility and outcomes of care provided to the patients (Pyrek 2014). Essential activities of infection control program include PI to decrease the healthcare-associated infection (HAI) and promoting quality healthcare (Freidman et al. 2008). Performance measurement is important to establish baseline performance to ensure that interventions are sustained over time, to get baseline analysis (comparison against benchmarks), selection of goals with achievable targets, and process/outcome measurement (Grota 2014). In our project, the team designed a control chart (process measurement) to monitor errors in performance in waste management process weekly to assess the stability of the improvement; the chart showed process shifting towards the desired direction of reduced errors in waste management performance. This will establish baseline data for us to compare for the next months and years. Sustained improvement will support our facility to follow the regulatory requirements needed to apply for accreditation. Developing countries have poor resources for safe management of hospital wastes. Rules and regulations focusing on management of medical waste are recently accomplished in many of these countries. Different hospitals show variable degrees of implementation of these rules. There is marked discrepancy in waste generation rates within each country and across countries. In general, hospitals in developing countries suffer from poor practices in waste sorting and segregation, handling, storage,

Table 5 Control measure spread sheet

\begin{tabular}{|c|c|c|c|c|c|c|}
\hline Variables & How & Where & Standard (\%) & Who analyze & Who act & What done \\
\hline Sorting (segregation) & Inspection & Interim storage room & 0 & IP & IP & $\begin{array}{l}\text { Increase awareness, } \\
\text { memo }\end{array}$ \\
\hline Sharp disposal & Check list & OR, clinics and, lab & 0 & IP & Supervisor of the place & Memo \\
\hline Waste bags disposal & Random check & All the hospital & 0.3 & $\mathbb{I P}, \mathrm{LN}$ & House keeping & $\begin{array}{l}\text { Investigate, increase } \\
\text { awareness }\end{array}$ \\
\hline $\begin{array}{l}\text { Cleaning of interim } \\
\text { storage room }\end{array}$ & Random check & Interim storage room & 0.3 & IP & House keeping & Investigate \\
\hline Timeliness & Log book & Different floors & 0.5 & $\mathbb{I P}$ & Link nurse & $\begin{array}{l}\text { Memo and schedule } \\
\text { distribution }\end{array}$ \\
\hline $\begin{array}{l}\text { Return to historic } \\
\text { mistake }\end{array}$ & Check list & Backyard & 0 & $\mathbb{I P}$ & Head of workers & $\begin{array}{l}\text { Further analysis and } \\
\text { investigation, memo }\end{array}$ \\
\hline
\end{tabular}

IP infection preventionist, $L N$ link nurse 


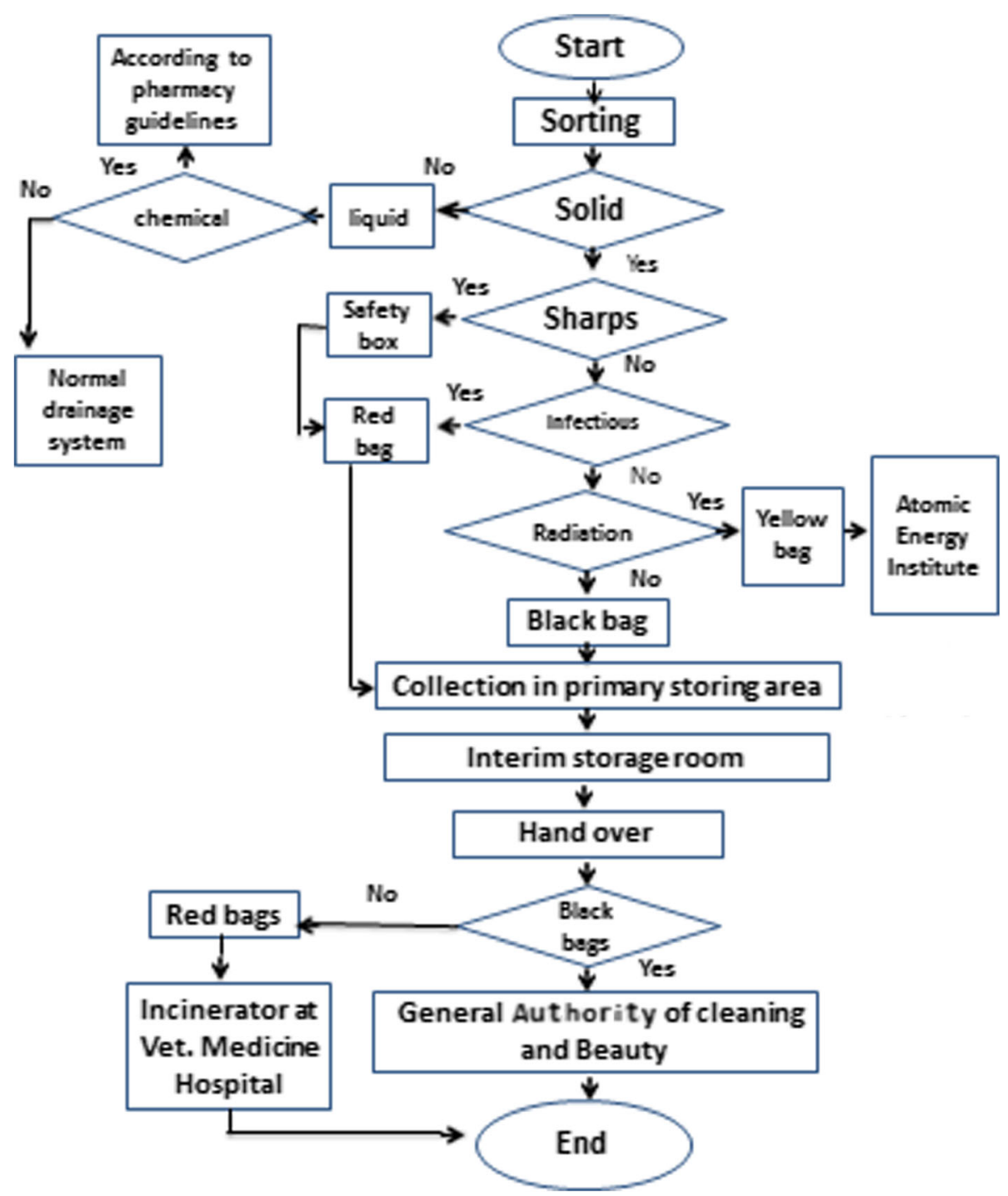

Fig. 5 High level flow diagram of steps of waste management process

transport, and final disposal (Ali et al. 2017). In Egypt, the issue of hazardous medical wastes management has acquired an increasing interest in the last two decades, as the awareness of their serious health effects has increased on both public and governmental levels (Shouman et al. 2013). According to $\mathrm{WHO}$, the average quantity of waste per bed per day is estimated to range from $0.7-1.7 \mathrm{~kg} / \mathrm{bed}$ in Egypt (Chartier et al. 2014); however, the composition of the waste stream considered hazardous and requiring special treatment may be higher than the expected 10 to $25 \%$ because of poor waste segregation in many studies (mixing hazardous with non-hazardous waste (Udofia et al. 2015; Haylamicheal et al. 2011; Abayomi and Tolulope 2017). Data obtained from the Ministry of Health in Egypt shows that the proportion of hazardous medical waste is in the range of 25-30\%, approximately (Egyptian Environmental Affairs Agency (EEAA) 2010; Rafeh et al. 2010;
Khayal and Zaki 2010). This big percentage may be due to inappropriate health care waste segregation. Contaminated environments increase the risk of transmission of healthcare-associated infections (Ambulatory Surgery Center ASC Quality Collaboration 2018). Unsafe injections with contaminated needles and syringes in developing countries have reduced markedly in recent years, as a result of the efforts made to prevent reuse of injection devices. However, in 2010, unsafe injections were found to be responsible for as many as 33,800 new HIV cases, 1.7 million hepatitis B cases, and 315,000 hepatitis C cases (Chartier et al. 2014) A previous study to detect prevalence of viral hepatitis $\mathrm{C}(\mathrm{HCV})$ antibodies among municipal solid waste (MSW) collectors in Mansoura, Egypt, demonstrated a high prevalence (43.3\%) of HCV antibodies among MSW workers. Statistically significant demographic variables for $\mathrm{HCV}$ antibodies seropositivity 
were encountered in the older age and the longer duration of employment of workers. That study clearly demonstrated the high risk of $\mathrm{HCV}$ infection among workers handling especially medical waste (El-Gilany et al. 2013). Therefore, safety measures including appropriate personal protective equipment must be available for those workers in addition to educational and training programs in order to do their job in a safe working environment. Risk groups in waste management process include medical doctors, nurses, volunteers, maintenance personnel, patients, visitors, workers in waste transportation to site of treatment, and workers in waste-management landfills (Maxwell 2018).

\section{Conclusion}

Overall, hospital waste management in developing countries faces several challenges. The safe management of health care wastes will help to avoid hazards to health and environment and prevent the unplanned release of biological or chemical threat, as well as drug-resistant microorganisms into the surrounding environment. Using our routine monitoring data, infection preventionist and public health professionals could help the organization to fulfill accreditation requirements for quality assurance through the performance improvement project which built awareness/consciousness among hospital staff and initiate some action programs to organize and control the existing waste management process which help in improving the quality of health care system.

\section{Acknowledgement}

Not applicable.

\section{Funding}

Not applicable

\section{Availability of data and materials}

All data generated or analysed during this study are included in this published article.

\section{Authors' contributions \\ AE had made the main contributions to work design, work as a member of the improving project team, supervised the data collection using check list, formulating data through using quality tools of diagrams and charts, drafting the manuscript, and revising and approving the final version before submission. She was responsible for the submission of the article as a corresponding author and performance of necessary revision and correction to the manuscript. MA has been involved in all the steps of project methodology, team formation, drafting the manuscript, revising of the tables and the references, and approving the manuscript for submission to the journal.}

\section{Ethics approval and consent to participate}

The work had been approved ethically and had the agreement of the Medical Research Committee of the Research Institute of Ophthalmology $\mathrm{RIO}$, Egypt, prior to the beginning of the study.

\section{Consent for publication}

Not applicable

\section{Competing interests}

The authors declare that they have no competing interests.

\section{Publisher's Note}

Springer Nature remains neutral with regard to jurisdictional claims in published maps and institutional affiliations.

\section{Author details}

${ }^{1}$ Infection Control Unit, Microbiology and Immunology Unit, Department of Microbiology and Parasitology, Research Institute of Ophthalmology (RIO),

Giza 12611, Egypt. ${ }^{2}$ Public Health Department, RIO, Giza, Egypt.

Received: 21 November 2018 Accepted: 30 January 2019

Published online: 18 February 2019

\section{References}

Abayomi SO, Tolulope OO (2017) Healthcare waste management practices and safety indicators in Nigeria. BMC Public Health 17:740. https://doi.org/10. 1186/s12889-017-4794-6 PMID: 28946876

Ale Livs (2013). New WHO handbook on healthcare waste management. News posted on August 5, 2013. Global tags: safe management of medical waste, WHO, handbook. https:/noharm-global.org/articles/news/global/new-whohandbook-healthcare-waste-management

Ali M, Wang W, Chaudhry N, Geng Y (2017) Hospital waste management in developing countries: a mini review. Waste Manage Res 35(6):581-592 https://doi.org/10.1177/0734242X17691344

Alzahrani Z, Jazieh A-R (2018) Forms and function. Six Sigma forum magazine, vol 18, p 2018 http://asq.org/six-sigma/2018/11/quality-tools/forms-and-function. html

Ambulatory Surgery Center ASC Quality Collaboration, (2018): Environmental infection prevention toolkit. http://www.ascquality.org/ EnvironmentallnfectionPreventionToolkit.cfm

Arthur J (2016) Excel power tools for lean Six Sigma in: lean Six Sigma for hospitals: improving patient safety, patient flow and the bottom line, 2nd edn. Mc Graw Hill companies, Library of Congress cataloging-in-publication data, New York, Chicago, San Francisco, pp 161-202

CDC-DHHS (NIOSH) (2004): Regulated medical waste. Self-inspection checklist. National Institute for Occupational Safety and Health. U.S. Department of Health \& Human Services. Publication Number 2004-101. https://www.cdc. gov/niosh/docs/2004-101/chklists/r1n79m 1.htm

Chartier Y, Emmanuel J, Pieper U et al (2014) Safe management of wastes from health-care activities, 2nd edn ISBN 9789241548564 http://www.who.int/ water_sanitation_health/publications/wastemanag/en/

Egyptian Environmental Affairs Agency (EEAA), (2010): Egypt state of environment report, Chapter 14. pp: 313-327. http:/www.eeaa.gov.eg/ portals/O/eeaaReports/SoE2011en/completereport/SOE-2010-En.pdf

El-Gilany A, Samir H, Abo-Elwafa et al (2013) Prevalence of hepatitis C virus antibodies among municipal solid waste collectors in Mansoura, Egypt. Occup Med Health Aff Research Gate December 2013.https://www. researchgate.net/publication/259043081_Prevalence_of_Hepatitis_C_Virus_ Antibodies_among_Municipal_Solid_Waste_Collectors_in_Mansoura_Egypt

Fakih MG, Heavens M, Ratcliffe CJ (2013) The IP's role in QAPI. First step to reducing infection risk as a system: evaluation of infection prevention processes for 71 hospitals. Am J Infect Control 41(11):950-954 https://www.ncbi.nlm.nih.gov/pubmed/23932829

Freidman C, Curchoe R, Foster M, Zahir Hirji Z et al (2008) APIC/CHICA-Canada infection prevention, control, and epidemiology: professional and practice standards. Am J Infect Control 36:385-389 https://doi.org/10.1016/ j.ajic.2008.04.246

Grota PG (2014) APIC text of infection control and epidemiology, vol 1, 4th edn section 2 chapter 16. Quality Concepts https:/pdfs.semanticscholar.org/596a/ 64f1371b63dfd624d1427e814bad6df57865.pdf

Haylamicheal ID, Mohamed AD, Yirsaw BD, Zegeye HA (2011) Assessing the management of healthcare waste in Hawassa City, Ethiopia. Waste Manage Res 29(8):854-862. https://doi.org/10.1177/0734242X10379496

Khayal A and Zaki T, (2010): Country report on the solid waste management Egypt, Sweep-Net the regional solid waste exchange of information and expertise network in Mashreq and Maghreb Countries. https://www.scribd. com/document/82256639/Rapport-Egypte-En

Langley GL, Nolan KM, Nolan TW, Norman CL, Provost LP (2009) The improvement guide: a practical approach to enhancing organizational performance, 2nd edn. Jossey-Bass Publishers. Institute for Healthcare Improvement.(2018) "How to Improve", San Francisco http://www.ihi.org/ resources/Pages/Howtolmprove/ScienceoflmprovementHowtolmprove.aspx 
Martin C (2005) Best management practices for hospital waste. Department of Ecology, Washington State, pp 1-8 Publication Number 05-04-013 December 2005.https://fortress.wa.gov/ecy/publications/SummaryPages/ 0504013.html

Maxwell M. (2018); Objectives of hospital waste management. https://bizfluent. com/about-5539524-objectives-hospital-waste-management.html

Pépin J, Abou Chakra CN, Pépin E et al (2014) Evolution of the global burden of viral infections from unsafe medical injections, 2000-2010. PLOS One 9(6):e99677

Pyrek K. M., (2014): Infection prevention boosted by quality improvement strategies. ICT. Infection control today, mar 17, 2014. https://www.infectioncontroltoday. com/best-practices-compliance/infection-prevention-boosted-qualityimprovement-strategies

Qandil A, et al (2016) National infection prevention and control manual, Ministry of Health and Population, Preventive Medicine, 3rd edn (Arabic version) Part

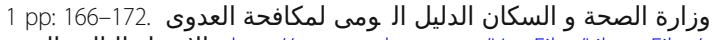
ورزارة http://www.mohp.gov.eg/UserFiles/LibraryFiles/ 832047.pdf.

Quinn D L (2018) What is six sigma? Blended learning for hospitality quality http://6sigma.weebly.com/whats-six-sigma.html

Rafeh N, Williams J, Hassan N (2010) Egypt, household health expenditure and utilization survey 2009-2010, vol 2011. Health Systems 20/20 project, Abt Associates Inc, Bethesda, pp 1-233 https://www.hfgproject.org/wp-content/ uploads/2015/02/Egypt-Household-Health-Expenditure-and-UtilizationSurvey-2010.pdf

Recommendations of CDC and the Healthcare Infection Control Practices Advisory Committee (HICPAC) (2003) Regulated Medical Waste in: Guidelines for Environmental Infection Control in Health-Care Facilities. U.S. Department of Health and Human Services Centers for Disease Control and Prevention (CDC) 24/7, GA 30329. Edit February 2017. https://www.cdc.gov/ infectioncontrol/guidelines/environmental/

Shouman E, Al Bazedi D, Sorour MH, Abulnour AG (2013) Management of hazardous medical waste treatment in Egypt. World Appl Sci J 28(6):804-808. ISSN 1818-4952. https://doi.org/10.5829/idosi.wasj.28.06.13847

Udofia EA, Fobil JN, Gabriel Gulis G (2015) Solid medical waste management in Africa. Afr J Environ Sci Technol 9(3):244-254. https://www.ajol.info/index. php/ajest/article/view/118218. Accessed 17 Nov 2018.

WHO, Fact Sheet, (2018). Health-care waste. 8 Feb 2018. http://www.who.int/ news-room/fact-sheets/detail/health-care-waste

\section{Submit your manuscript to a SpringerOpen ${ }^{\circ}$ journal and benefit from:}

- Convenient online submission

- Rigorous peer review

- Open access: articles freely available online

High visibility within the field

- Retaining the copyright to your article

Submit your next manuscript at $\boldsymbol{\nabla}$ springeropen.com 